\title{
Australian investors lose tax incentives on innovation
}

US industry lobbies for extension of \$3bn tax credit schemes

Sydney. In its first significant change to Australian research policy, the new Coalition government has cancelled a scheme that has used tax incentives to encourage investors to form 'syndicates' for commercializing the results of research.

Australian researchers and government departments have long been trying to boost local industry and to increase the low level of investment by financial institutions in science and technology. In 1986, the former Labor government introduced an attractive 150 per cent tax rebate on approved expenditure by industry on in-house research and development. This incentive, worth A $\$ 550$ million (US $\$ 433$ million) in 1994-95, will be retained and "fine-tuned".

The syndication scheme - believed to be unique to Australia - was introduced in 1987. It allowed tax concessions of 100 per cent on losses to investors on money that was gathered by financial houses into lump sums for use by companies in the commercialization of discoveries. On the recommendation of the Bureau of Industry Economics, the scheme has now been cancelled by the Treasurer, Peter Costello, and the industry minister, John Moore.

Any debate or lobbying to retain the scheme was forestalled by announcing the decision on the day the bureau's report was released. Citing four unnamed examples of alleged abuses, the ministers claimed that syndication had "become focused on tax minimization rather than the provision of genuine research and development".

They added that the government was concerned about the amount of tax revenue lost through tax concessions, which

amounted to A $\$ 255$ million for 217 syndicates in 1994-95.

The international quality of biomedical research in Australia's universities and public agencies attracted many of the syndicates. The University of Sydney, for example, collaborated with the Commonwealth Scientific and Industrial Research Organisation, the AMRAD company and Macquarie Bank (which raised A $\$ 20$ million over three years) to develop an antiviral drug to treat a strain of hepatitis.

Graham Johnston, a pharmacologist involved in the collaboration, says that it has been one of the most exciting times of his research career. It has brought together three groups of partners - researchers, industry people and financiers - for a targeted programme. Johnston and others had been calling for the syndication scheme to be retained, but with tighter rules. The Federation of Australian Science and Technology Societies wanted a peer-reviewed scheme of direct funding to be added.

The government says it will now "consider" a new programme of grants or loans. Urgent consultations have begun to devise a scheme before the release on 20 August of its first budget, which is predicted to bring cuts of $\mathrm{A} \$ 4$ billion.

Although existing syndicates will be able to continue, the withdrawal of tax benefits has already prompted several potential investors to cancel negotiations over investments in local research efforts, and has led some observers to predict that there will be an increase in the number of Australian innovations that are now developed by overseas companies.

Peter Pockley

\section{Indian budget boosts AIDS research}

New Delhi. The Indian government has allocated the equivalent of US\$1,516 million ( 5.4 billion rupees) for research and development in the 1996-97 budget, about $\$ 60$ million more than last year. But scientists say this represents a cut in real terms because the value of the rupee has fallen by 6 per cent.

Funding for AIDS research and control has been doubled to $\$ 40$ million, however, more than 40 per cent of the total allocation for medical research. Research in herbal medicine has also received a boost, with a provision of $\$ 12$ million.

Few new research projects have been announced. The Department of Biotechnology will set up a \$2.5-million centre for DNA fingerprinting and diagnostics in
Hyderabad, and the space department has announced plans to build and launch next year a \$12-million satellite, OceanSat, to monitor the resources of the seas around India.

Although scientists are disappointed by the budget, they have welcomed the government grant of $\$ 8.6$ million to the technology development fund. This was created two years ago to help commercialization of home-grown technologies. They have also welcomed the announcement of a grant to modernize the 80 or so industrial and agricultural laboratories. The amount has not been specified but it will be equal to what the laboratories earn through consultancy services and commercialization of the technologies they develop. K. S. Jayaraman
Washington. The extension of two research tax credits worth about $\$ 3$ billion are at stake in a bill being finalized this week in the US House of Representatives and Senate. President Bill Clinton has urged Congress to send him the bill to sign into law before it goes into summer recess.

The two tax credits - one to entice companies to expand their general research and development, the other to encourage the development of drugs against rare diseases - lapsed in 1995 and 1994 respectively. A minimum wage bill passed by the Senate in June extends the two credits for 18 months, beginning on 1 July 1996. But the version of the bill passed by the House, which raises the minimum hourly wage from $\$ 4.25$ to $\$ 5.15$, contains no such provisions.

Industry has been lobbying not only for the inclusion of the measures in the final bill, but also for amendments to enable companies to claim the credits retroactively.

The 'orphan' drug credit allows companies to subtract from their taxes 50 per cent of the costs of human clinical testing of orphan drugs, defined as those with disease populations of fewer than 200,000 . They are so-called because advocates say the drugs were "orphaned" in the past by pharmaceutical companies.

The research and experimentation credit allows companies to subtract from their taxes 20 per cent of expenditure on new research and development.

Influential members of Congress have joined groups such as the Biotechnology Industry Organization (BIO) in pushing for the retroactive extension of the credits, a position which the Clinton administration also supports. In June, a bipartisan group of 33 senators wrote to leaders of the negotiations, calling the lapse in the credits "a troubling signal" to industry and a threat to US competitiveness that would "severely impact companies' commitment to research".

But Senator William Roth (Republican, Delaware), chairman of the Senate Finance Committee and the lead negotiator, opposes retroactive extension. "It is to be used as an incentive and to make it retroactive would defeat the purpose," says Ginny Koops, a spokeswoman.

And fiscal conservatives are concerned about the costs of extending the credits. Congress's Joint Committee on Taxation puts the cost of the research credit extension at $\$ 2.9$ billion, and the orphan-drug credit extension at $\$ 44$ million.

Orphan drug developers are hoping for the retention of a provision in the Senate bill that would allow companies to claim the credit up to 14 years after research costs were incurred. 